\title{
Changes in protein profile and encapsulation avoiding responses of entomopathogenic nematode in the American bollworm Helicoverpa armigera (Hübner) (Lepidoptera: Noctuidae)
}

\author{
Istkhar ${ }^{* *}$ and Ashok Kumar Chaubey ${ }^{2}$
}

\begin{abstract}
The American bollworm Helicoverpa armigera (Hübner) (Lepidoptera: Noctuidae) is a highly destructive agriculture pest of worldwide importance. The aim of the present study was to infect $H$. armigera larvae with entomopathogenic nematode juveniles for hematological study of proteins and encapsulation responses to evaluate using this nematode for the management of this pest. Total protein estimation and the electrophoretic profiling carried out in the hemolymph showed a high pathogenicity of Steinernema abbasi to H. armigera. The control group survived and succeeded to develop to adults, while the infected ones died within $24 \mathrm{~h}$. An increase in the protein contents in the total and plasma hemolymph was observed just after $3 \mathrm{~h}$ of infection with an increase at $6 \mathrm{~h}$ and $9 \mathrm{~h}$ as symptoms of early defence of the insect. SDS-PAGE profile also showed an evolvement of a protein band of $46 \mathrm{kDa}$. No selfassociation or aggregation and binding of other proteins were found in the hemolymph as revealed by Native-PAGE. The encapsulation avoidance rate of nematode juvenile gave good results with (> 33\%) in $2 \mathrm{lJs} / \mathrm{larva}$ to $5 \%$ in $20 \mathrm{lJs} /$ larva doses at $24 \mathrm{~h}$ post infection. Loss of hemolymph proteins continued for more than $24 \mathrm{~h}$ with a very low recognition of nematode rate in hemolymph, followed by the death of larvae within $48 \mathrm{~h}$, which proved the high pathogenicity of S. abbasi and suppression of host immune system of H. armigera.
\end{abstract}

Keywords: Helicoverpa armigera, Entomopathogenic nematode, Steinernema abbasi, Protein estimation, Encapsulation

\section{Background}

Insect immunology is a rapidly growing discipline with exciting and innovative application, especially in control of agricultural pests by understanding the host parasite interactions such as entomopathogenic nematodes (EPNs). When insect pests of agricultural crops are targeted by microorganisms, they rely on innate immunity for quick response comprises cellular and humoral activity.

The American bollworm, Helicoverpa armigera (Hübner) (Lepidoptera: Noctuidae), is a polyphagous worldwide distributed pest infests more than 181 plant species belonging to 45 families (Singh 2005). Defensive strategies

\footnotetext{
* Correspondence: istkharrao@gmail.com

'Department of Bioscience and Biotechnology, Banasthali Vidyapith,

Banasthali, Rajasthan 304022, India

Full list of author information is available at the end of the article
}

of $H$. armigera are poorly understood, and this insect has developed a strong resistance against several chemical pesticides (Bass et al. 2015). Studying the immune system of pests helps better understanding of their defenses against invading parasites (EPNs), which are nowadays been used in insect pest management. In this regard, less information is available on immunological defenses in hemolymph of $H$. armigera creating its management difficult. Results of pathogenicity of EPNs against $H$. armigera larvae provided a good picture and better management in a comparatively environmentally safer way (Istkhar and Chaubey 2017).

The EPNs, steinernematids and heterorhabditids have become a new tool as they have a wide variety of host range, high virulence, less killing time, host finding ability, fast acting generations, and safe to vertebrates and non-target invertebrates (Lacey and Georgis 2012). Steinernematids 
are naturally associated with symbiotic bacteria of the genus Xenorhabdus (Gammaproteobacteria: Enterobacteriaceae). Researchers showed that not only the nematodes, but also the bacterial symbionts are highly pathogenic to many insect pests once they reached the hemocoel of the insect (Forst and Nealson 1996). During their complex life cycle in a common insect host, bacteria carried by the nematodes in their gut are regurgitated in the hemocoel of insect, where they multiply along with nematodes and produced several toxins, leading to the death of insect. Hemolymph plays a vital role for insects as the place where they compete with invading microorganisms. Production of antimicrobial peptides (AMPs), activation of melanization, phagocytosis, and encapsulation are the main events against EPN infection in the insect hemolymph (Castillo et al. 2011). When the nematode enters in the hemocoel of insect, soluble proteins in hemolymph and proteins released by hemocytes and hematopoietic organs participate in their encapsulation (Lemaitre and Hoffmann 2007). To avoid the targeting, nematode and/or nematode-bacterial complex also attempt to evade the poorly understood immune response of insect immune system (Brivio et al. 2010). Little information is available about the nematode infection and hematological changes in $H$. armigera.

The present study was planned to study the hematological responses of $H$. armigera larvae infected with 3rd stage infective juvenile (IJs) of Steinernema abbasi for protein and nematode encapsulation.

\section{Materials and methods}

\section{Insect's maintenance}

Eggs of $H$. armigera were obtained from the National Bureau of Agriculturally Important Resources (NBAIR), ICAR, Bangalore, India (National Accession No. NBAIIMP-NOC-01), and the culture was maintained in the laboratory. Larvae were fed on a semisynthetic diet (Nagarkatti and Prakash 1974), while the adults were fed on $10 \%$ honey solution containing vitamin $\mathrm{E}$ for better egg laying. A culture of the greater wax moth, Galleria mellonella (L.) (Lepidoptera: Pyralidae), was also maintained in the laboratory for in vivo culturing of the EPNs.

\section{In vivo nematode culture}

Steinernema abbasi (Rhabditida: Steinerneamtidae) was found to be the most dominating and pathogenic species during the survey conducted in studied area and showed a strong pathogenicity to $H$. armigera (Istkhar and Chaubey 2017). Isolate $\mathrm{CS}_{2}$ of $S$. abbasi originally isolated from the soil of District Meerut (U.P.), India, was used to infect the larvae of $H$. armigera for hematological study. Population of S. abbasi was maintained in vivo on larvae of G. mellonella, which considered as the universal host of EPNs. Freshly emerged 3rd stage infective juvenile (IJs) were collected from White trap (Stock and Goodrich-Blair 2012) and stored in BOD at $15 \pm 1{ }^{\circ} \mathrm{C}$ and used to infect the larvae of $H$. armigera for experimentation within a week of emergence.

\section{Experimental design for protein estimation}

For studying the changes in protein quantity and protein profiling through electrophoresis in hemolymph of $H$. armigera, the hemolymph was collected at different post infection periods (PIP) after infection with 100 IJs of $S$. abbasi (isolate $\mathrm{CS}_{2}$ ) in six-well Petri plates (Himedia) lined with a double layer of Whatman filter Paper (No. 1) by maintaining the adequate moisture. Larvae were then surface sterilized and $50 \mu \mathrm{l}$ of hemolymph from each larva was drawn directly in pre-chilled $1.5 \mathrm{ml}$ centrifuge tubes containing $450 \mu \mathrm{l}$ of phosphate buffer saline (PBS, pH 7.2) by cutting their proleg at $0,3,6,9$, 12,18 , and $24 \mathrm{~h}$ post infection period (PIP). Control group received $450 \mu \mathrm{l}$ of distilled water and used for hour to hour protein comparison. Control and treated group were placed in $\mathrm{BOD}$ at $27^{\circ} \pm 2{ }^{\circ} \mathrm{C}$. For each hour interval, 10 out of 20 infected larvae were randomly selected for hemolymph collection, and the whole experiment was repeated twice. Hemolymph of larvae in the control group was also collected in a similar way. Hemolymph was collected singly from each larva, and mean values of 10 replicates were taken as mean quantity of protein in milligram/milliliter of hemolymph.

\section{Protein estimation}

For the assessment of combined effect of soluble proteins and hemocytic protein (proteins secreted by hemocytes) changes due to nematode infection in hemolymph and soluble proteins only, the hemolymph samples were tested as total hemolymph and plasma fractions, respectively. Total protein contents in plasma fraction of hemolymph samples, collected from the infected and control larvae of $H$. armigera in PBS solution $(\mathrm{pH} 7.2)$, were estimated according to Bradford's method (Bradford 1976). Twohundred microliters of the hemolymph-PBS mixture mentioned above was retained as a whole hemolymph, and the rest was centrifuge at $10,000 \mathrm{~g}$ for $20 \mathrm{~min}$ at $4{ }^{\circ} \mathrm{C}$ to separate out plasma contents. Protein was estimated as total protein in hemolymph and in plasma fraction in terms of soluble proteins. Both samples were used for protein estimation and were expressed in milligram/milliliter of hemolymph. Dilutions of bovine serum albumin (BSA) were used to prepare a standard curve for estimation of protein.

\section{Electrophoresis of hemolymph samples}

Reducing electrophoresis of cell-free hemolymph was performed using $12 \%$ resolving and $4 \%$ stacking polyacrylamide gel (SDS-PAGE) (Laemmli 1970) on Genei electrophoretic unit for 1-D gel electrophoresis using 
power supply set at $15 \mathrm{~mA}$ for $10 \mathrm{~min}$ and at $30 \mathrm{~mA}$ for $120 \mathrm{~min}$. A broad range $(10-250 \mathrm{kDa})$ multicolour ladder (Thermo Scientific ${ }^{\mathrm{TM}}$ ) was run along with hemolymph samples for estimating and comparing changes in protein samples. Lanes of gel were loaded with 5- $\mu$ l plasma sample side by side collected from parasitized and unparasitized larvae of $H$. armigera, respectively. After electrophoresis, the gels were stained, using coomasie brilliant blue R250 stain. The analyses of gels were performed through My Image Analysing Software Version 2.0 (Thermo Scientific). For non-reducing electrophoresis, Native-PAGE was performed for all the samples to study self-association or aggregation and the binding of other proteins if any.

\section{Experimental design for encapsulation responses}

The encapsulation responses of host insect $H$. armigera were investigated by injecting IJs/larva (Peters and Ehlers 1997) directly into the hemocoel. The encapsulations were observed microscopically after $24 \mathrm{~h}$ as after $48 \mathrm{~h}$ all the larvae were found dead. To ensure the entry of nematode IJs, an injection apparatus modified from Ehlers et al. (1997) (Fig. 1) was constructed, using a capillary tube inserted and sealed in a microtip of $20 \mu \mathrm{l}$ capacity. The tip of the capillary tube was heated, drawn out, and broken into fine pointed tip. The other end of the capillary tube was fixed into the microtip and placed over the micropipette ensuring the fixed amount of nematode suspension to be injected into the body cavity of insect larvae. Eighty larvae were injected by 4 different doses of IJs having 2, 5, 10, and 20 IJs of nematode in 8 $\mu \mathrm{l}$ of PBS solution (Himedia) and dived into 2 batches. The first batch was infected with IJs was dissected to observe the total number of IJs encapsulated and studied under stereomicroscope (NIKON SMZ645). The second batch was placed to observe the mortality rates at the tested doses of nematode IJs applied at the same time of dissection. Ten replicates were maintained for each dose of injection. Ten larvae of $H$. armigera received only PBS solution and placed as control. Larvae were dissected after each $24 \mathrm{~h}$ of infection, and numbers of encapsulated nematode juveniles were counted. The larvae were disinfected by $70 \%$ alcohol before injecting.

\section{Statistical analyses}

Descriptive analysis was performed for quantified protein at each hour interval and presented as mean \pm standard error of mean (SEM) of 10 replicates randomly selected from infected with EPNs and control larvae of $H$. armigera. Two-way ANOVA was performed to find out the effect of time and treatment on total protein contents. One-way ANOVA was executed to compare protein differences in infected and control larvae. Fisher's least significance difference (Fisher's LSD) was used as post hoc test for comparison within infected and control at each hour interval.

\section{Results and discussion}

In the present study, the estimation of protein was performed, followed by their electrophoretic profiling. The total protein contents were measured in total and plasma fraction of larval hemolymph of $H$. armigera infected with S. abbasi-X. Indica separately. Analysis of variance (two-way) showed that total protein contents in total hemolymph challenged with $S$. abbasi was affected by time ( $\mathrm{df}=6 ; F=14.584 ; p=0.00)$ and not by treatment $(\mathrm{df}=1 ; F=1.388 ; p=0.241)$. Effect of time and treatment interaction was significant $(\mathrm{df}=5 ; F=17.784$; $p=0.00$ ). While applying one-way ANOVA, the mean protein contents varied significantly between the infected and control group of $H$. armigera larvae $(\mathrm{df}=12$; $F=14.825 ; p=0.00$ ) (Fig. 1a). Insignificant changes were recorded in the control group and the amount of protein was almost steady with very minute fluctuations from 129.23 to $129.62 \mathrm{mg} / \mathrm{ml}$. The increment in protein contents was reported over $3 \mathrm{~h}$ of infection. This significant increment was $12 \%$ as compared to $0 \mathrm{~h}$ from 129.49 to $144.81 \mathrm{mg} / \mathrm{ml}(p<0.05)$. With the significant increments of 24.69 and $28.27 \%$ protein contents at $6 \mathrm{~h}$ and $9 \mathrm{~h}$, respectively, an increment in protein profile was detected in the total protein amount reaching the peak amount of $165.77 \mathrm{mg} / \mathrm{ml}$. From $9 \mathrm{~h}$ PIP onwards, a dramatic decline was recorded continuously up to $24 \mathrm{~h}$ with 116.92 $\mathrm{mg} / \mathrm{ml}, 109.55 \mathrm{mg} / \mathrm{ml}$, and $97.50 \mathrm{mg} / \mathrm{ml}$ at 12,18 , and $24 \mathrm{~h}$, respectively. In a similar way, soluble protein content fluctuated significantly in the plasma fraction of hemolymph (Fig. 1b).

The protein contents in plasma fraction measured lower than the total hemolymph. Two way ANOVA established a significant effect of time ( $\mathrm{df}=6 ; \mathrm{F}=15.346 ; p=0.00)$ and nematode infection $(\mathrm{df}=1 ; F=6.003 ; p=0.016)$ indicating the main role of soluble proteins in combat with the parasitic infection. With the increment in the time, the nematode-bacterium significantly affected the plasma protein contents $(\mathrm{df}=5 ; F=18.580 ; p=0.00)$ of $\mathrm{H}$. armigera larvae. One-way ANOVA displayed a significant result, when comparing the protein contents in control and infected larvae $(\mathrm{df}=6 ; F=15.957 ; p=0.00)$. A $26.26 \%$ increment ( 110.26 to $139.30 \mathrm{mg} / \mathrm{ml}$ ) in protein content was found in the plasma fraction after $3 \mathrm{~h}$ of infection, reaching 47.59\%) within $9 \mathrm{~h}(163.01 \mathrm{mg} / \mathrm{ml})$ of infection. From this point onwards, the protein content decreased up to $96.67 \mathrm{in} 12 \mathrm{~h}, 86.48 \mathrm{in} 18 \mathrm{~h}$, and $77.12 \mathrm{mg} / \mathrm{ml}$ in $24 \mathrm{~h}$ after larval infection with nematodes. A similar pattern was observed in total protein contents in the whole hemolymph. Results obtained from previous hemocytic studies revealed that hemocytes of $H$. armigera played an important role during the nematode-bacterial infection (Istkhar and 


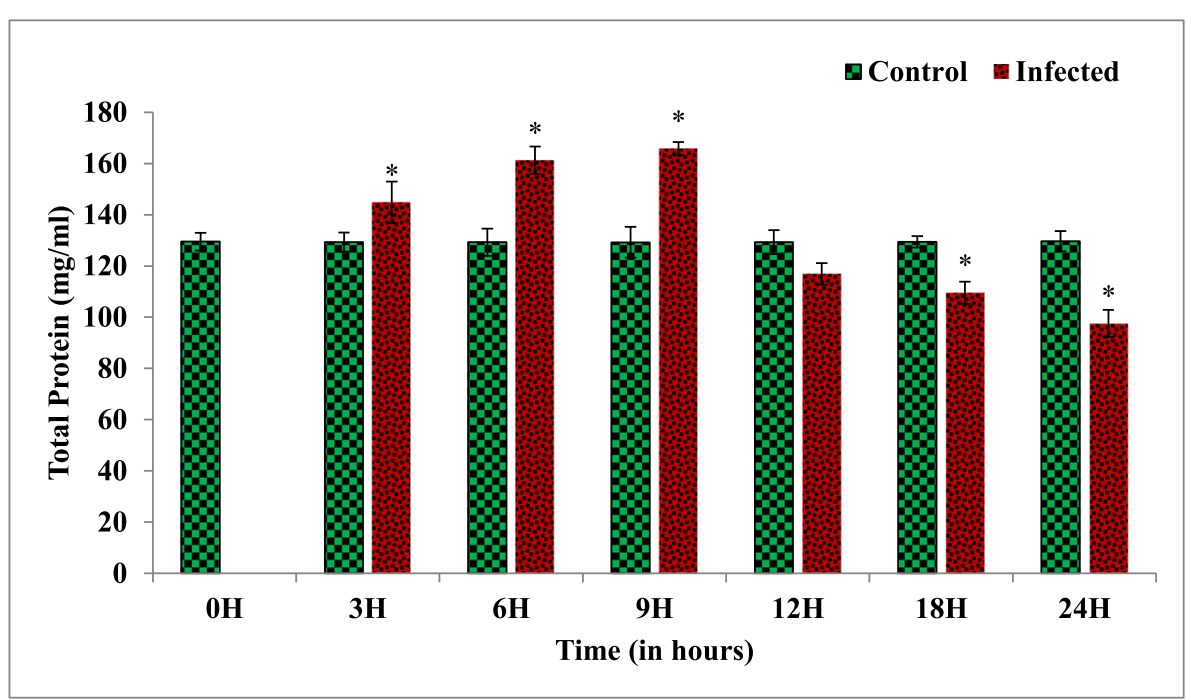

a.

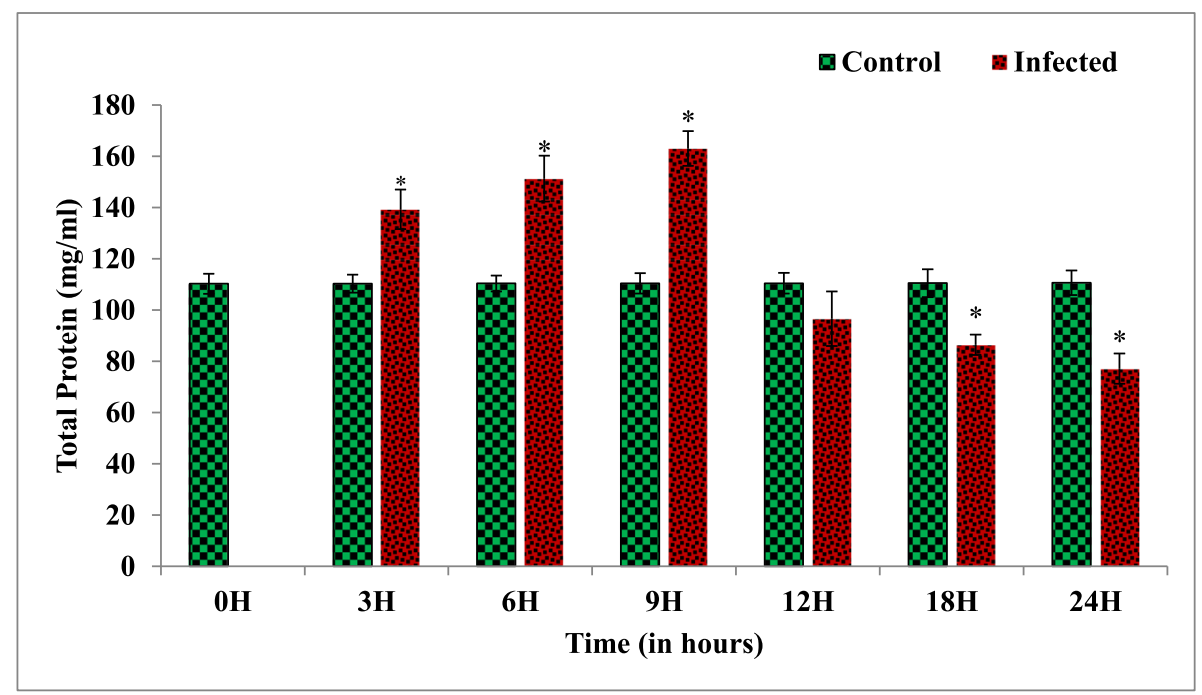

b.

Fig. 1 Concentration of total protein in larval hemolymph (a) and plasma (b) of Helicoverpa armigera infected with Steinernema abbasiXenorhabdus indica complex at different $0,3,6,9,12,18$, and $24 \mathrm{~h}$. Error bars indicate SEM. The asterisk above the error bars showed that the data was statistically significant at pairwise difference (Fisher's LSD)

Chaubey 2018). Increment observed in protein contents by spectrophotometric study, just after $3 \mathrm{~h}$, indicated the activation of $H$. armigera immune system responses by detecting nematode IJs which may be considered an early defense mechanism. The superior pathogenicity of Steinernema species perceived with the entry of the IJs in the insect host's body confirmed by the elevated profile of protein in the hemolymph samples, which was almost steady in the control group up to $9 \mathrm{~h}$.

During the analysis of separation of plasma protein contents through SDS-PAGE, lanes were loaded alternatively by plasma fractions of control and infected larval hemolymph plasma of $H$. armigera. The electrophoretic profile revealed the 8 major bands of proteins in hemolymph plasma with molecular weights of $\sim 173, \sim$ 96, 68, 59, $~ 52, \sim 48, \sim 34$, and $\sim 17 \mathrm{kDa}$ (Fig. 2). In nematode-bacterium challenged larvae an additional band of $\sim 46 \mathrm{kDa}$ was observed at 9 and $12 \mathrm{~h}$ of PIPs. This band vanished at $18 \mathrm{~h}$ of infection and a new band appeared at $24 \mathrm{~h}$ of infection with molecular weight of $\sim 28 \mathrm{kDa}$. When the plasma fractions were analyzed in non-denatured conditions, there were 5 major bands (Rf values $0.09,0.15,0.38 .0 .53$, and 0.57 ) in the gel and no changes were observed revealed by Native-PAGE electrophoretic profile in control and infected groups of $H$. armigera (Fig. 3). Electrophoretic study performed on 


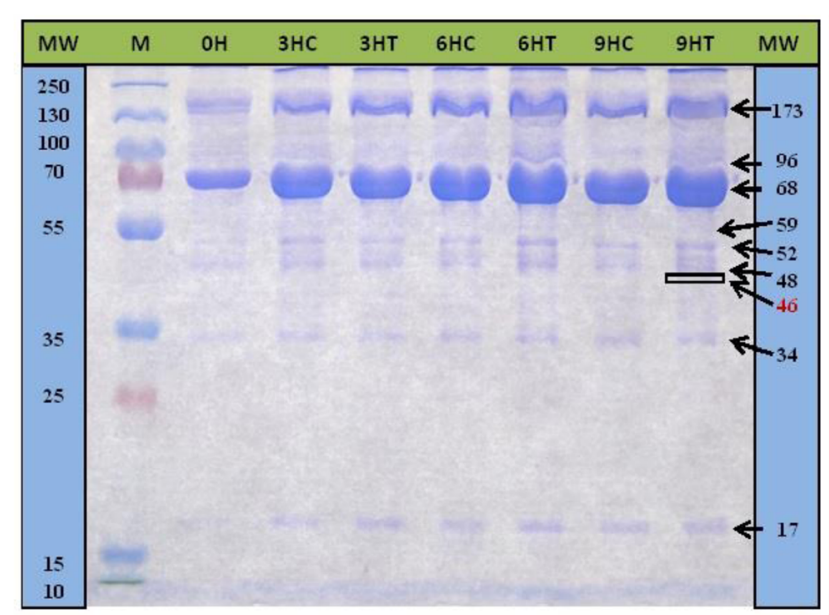

a.

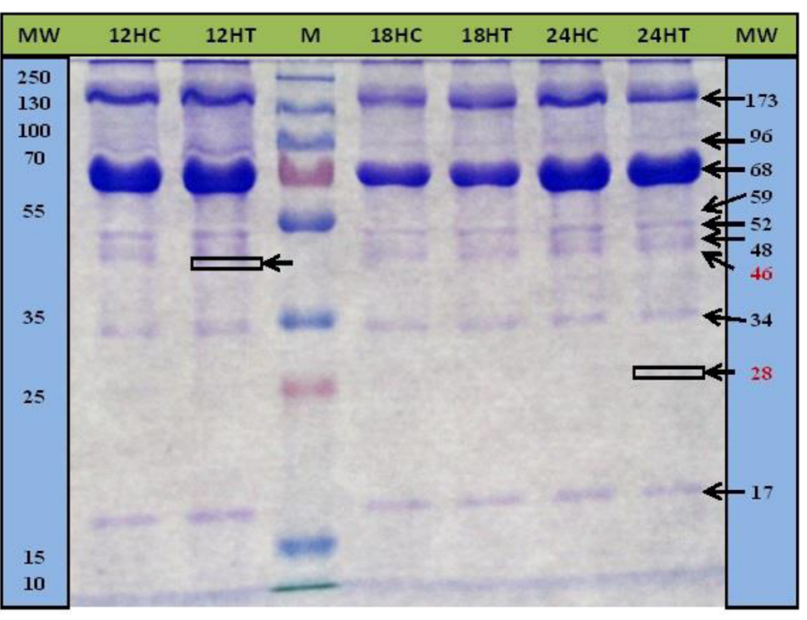

b.

Fig. 2 A comparative electrophoretic profile of plasma fractions of a control $(0,3 \mathrm{HC}, 6 \mathrm{HC}, 9 \mathrm{HC})$ and Steinernema abbasi-Xenorhabdus indica infected (3HT, 6HT, 9HT) Helicoverpa armigera, b control $(12 \mathrm{HC}, 18 \mathrm{HC}, 24 \mathrm{HC})$ and Steinernema abbasi-Xenorhabdus indica infected (12 HT, 18HT, 24HT) H. armigera analyzed by SDS-PAGE. Gels were analyzed through My Image Analysing Software Version 2.0 (Thermo Scientific)

Rhipicephalus microplus (Boophilus) infected with Heterorhabditis indica showed no differences in SDS-PAGE profile of hemolymph proteins (Patrícia Silva Golo et al. 2016). In our study, the electrophoretic patterns of infected and control hemolymph was almost similar; however, the appearance and disappearance of proteins were observed in denatured electrophoretic profile at $9 \mathrm{~h}, 12 \mathrm{~h}$, and $24 \mathrm{~h}$ in infected hemolymph. This can be explained as after entry of nematode-bacterium complex within the body of $H$. armigera, the host produces some defensive factors to combat with invading pathogens. The proteins are secreted during the initial phase of nematode growth more abundantly (Simões et al. 2000) as observed in the present study, where the amount of proteins in hemolymph increased significantly during initial hours of infection. The increment reported in hemocytes during initial hours of infection in the previous study (Istkhar and Chaubey 2018) acclaimed the increment in protein

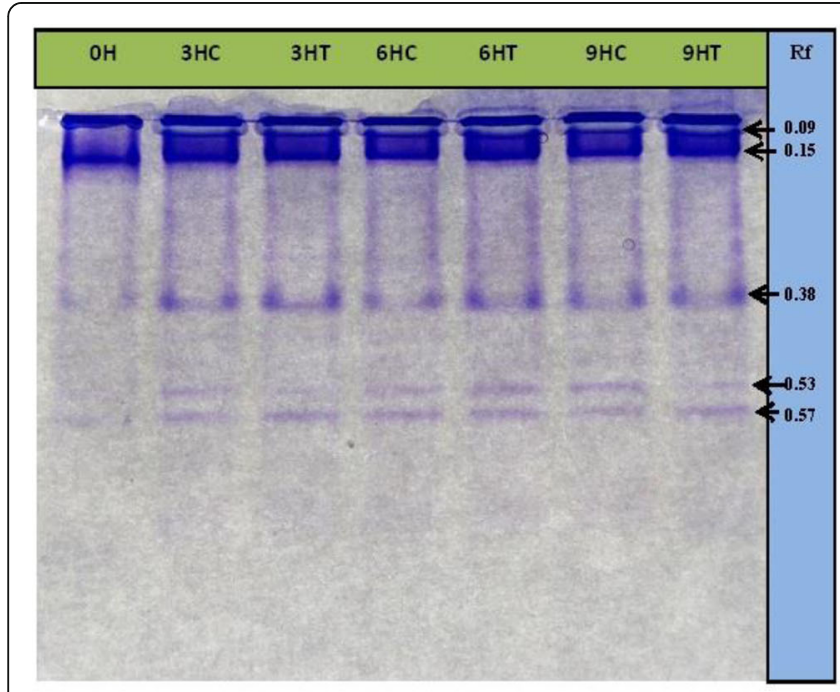

a.

Fig. 3 A comparative electrophoretic profile of plasma fractions of a control $(0,3 \mathrm{HC}, 6 \mathrm{HC}, 9 \mathrm{HC})$ and Steinernema abbasi-Xenorhabdus indica infected $(3 \mathrm{HT}, 6 \mathrm{HT}, 9 \mathrm{HT})$ Helicoverpa armigera, b control $(12 \mathrm{HC}, 18 \mathrm{HC}, 24 \mathrm{HC})$ and Steinernema abbasi-Xenorhabdus indica infected $(12 \mathrm{HT}, 18 \mathrm{HT}$, 24HT) H. armigera analyzed by NATIVE-PAGE. Gels were analyzed through My Image Analysing Software Version 2.0 (Thermo Scientific) 
contents in present study and showed the secretion of some major proteins of hemolymph and some unknown proteins by hemocytes, which may help in initial protection and defend host to parasitic infection. This statement was supported by the presence of extra band at $9 \mathrm{~h}$ of infection. The disappearance of proteins bands occurred at 9 and $12 \mathrm{~h}$ as well as in the total protein contents were explained as the action of hydrolysing of the host proteins. These results agree with the Schmidt and Platzer (1980), who reported protein degradation, when Culex pipiens (L.) was infected by Romanomermis culicivorax. They suggested the production of some proteases from the nematodes leads to the degradation of hemolymph proteins of
C. pipiens. Wee et al. (2000) suggested the production of proteases by bacterial cells, followed by the breakdown of insect's protein and serving as nutritional resources for nematode-bacterium development. In another study, the reduction in total protein contents of hemolymph was observed in the hemolymph of Schistocerca gregaria (Forsskall) during the course of infection with EPF, Mertarhizium anisopliae var acridium (Gillespie et al. 2000). Other workers supported the study, where the productions of proteases and subsequent reduction in proteins by Steinernema carpocapsae and bacteria were reported (Toubarro et al. 2013). While studying the electrophoretic band pattern in native-PAGE for the agglutination and/or

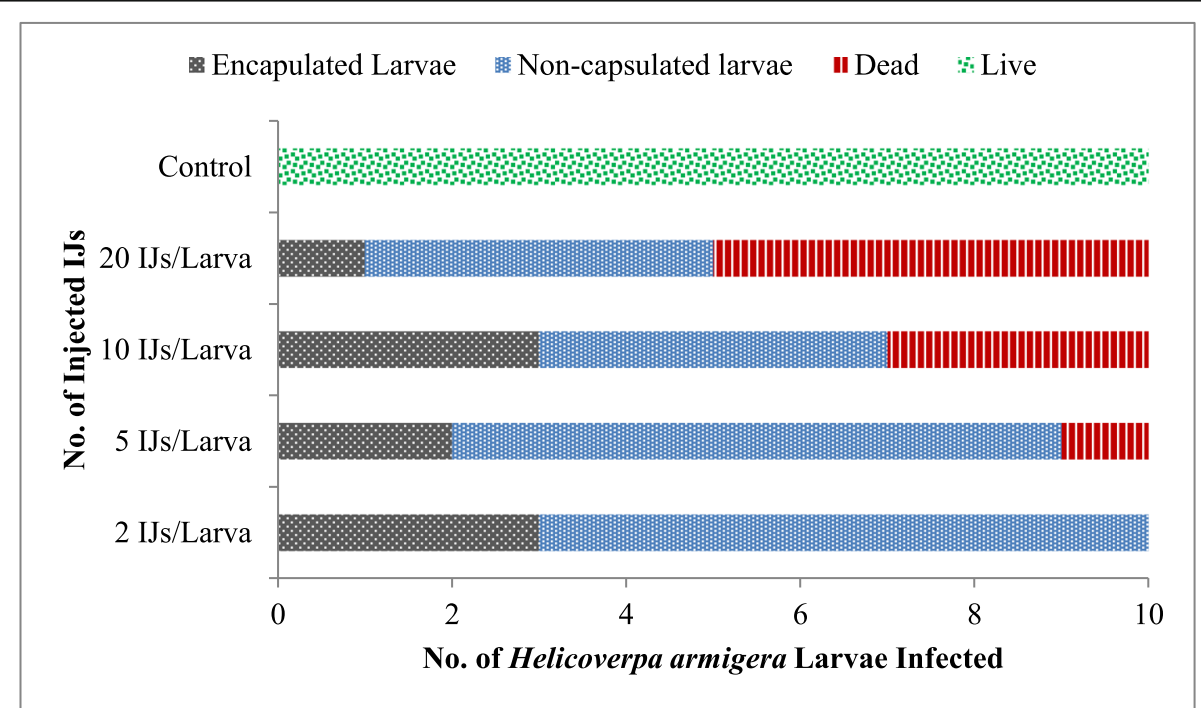

a.

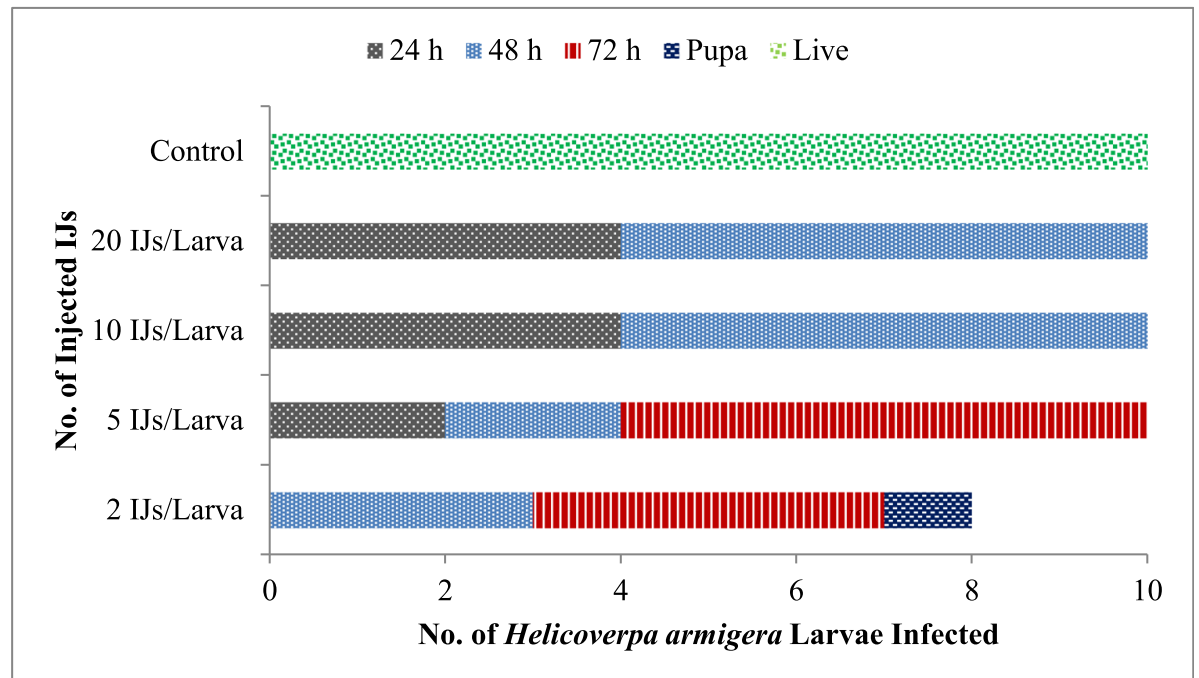

b.

Fig. 4 Encapsulation responses of Helicoverpa armigera infected with Steinernema abbasi-Xenorhabdus indica complex. a First batch of larvae dissected for encapsulation. $\mathbf{b}$ Second batch of larvae showing rate of mortality 
association of proteins during infection, no changes were observed and similar pattern banding was found in the control and the infected groups.

For encapsulation study, the first batch of nematodeinfected larvae was dissected after $24 \mathrm{~h}$ only and not after $48 \mathrm{~h}$ as infected larvae were found dead after $48 \mathrm{~h}$. During the time of dissection, the adhering of hemocytes was observed around the encapsulated nematode. In the first batch, 30, 20,30, and $10 \%$ of larvae injected with 2, 5, 10, and 20 IJs of nematode were found having encapsulated IJs within their hemocoel. No strong melanization was noticed over encapsulated IJs. Mortality was observed in the larvae and 10, 30, and 50\% mortality rates were found in $H$. armigera larvae infected with 5,10 , and $20 \mathrm{IJs}$ /larva, respectively, at $24 \mathrm{~h}$ (Fig. 4a). No mortality was observed in the larvae injected with 2 IJs/larva. In a second batch of larvae injected with nematode, all nematodes were found dead in dissected larvae at $48 \mathrm{~h}$ in 10 and 20 IJs/larva doses, whereas in 2 and $5 \mathrm{IJs} /$ larva doses, 70 and $80 \%$ after $72 \mathrm{~h}$ and one of the larvae attained pupation, but could not achieved emergence (Fig. $4 \mathrm{~b}$ ). The percentage of encapsulation of IJs was calculated in the larvae found positive for encapsulation, when injected with different doses of IJs. The proportion of encapsulated nematodes declined with increasing dose from $66.67 \%$ for 2 IJs/larva to $5 \%$ for $20 \mathrm{IJs} /$ larva. For 5 and $10 \mathrm{IJs} /$ larva, the encapsulation was 30 and $16.67 \%$, respectively.

However, EPNs were found effective against the insect pests; the insect has also evolved defensive mechanisms against these nematode invaders (Feldhaar and Gross 2008). The innate immune responses included hemocytes, which participated in phagocytosis, nodulation, and encapsulation, and played a significant role and provide a protection to the insect hosts (Schmidt et al. 2001). The increments in hemocyte number in hemolymph of $H$. armigera infected with $S$. abbasi have already been observed in previous study (Istkhar and Chaubey 2018). The encapsulation responses of different hosts varied according to host species and nematode species. In Manduca sexta (L.), H. bacteriophora was recognized by (> $99 \%$ ) value, while S. glaseri showed only (28\%) recognition (Li et al. 2009). The encapsulation study of S. feltiae and $H$. bacteriophora, against the prepupae of Leptinotarsa decemlineata (Say) showed a more frequent encapsulation of $S$. feltiae than for H. bacteriophora (Ebrahimi et al. 2011). On the other hand, in the rose sawfly Arge ochropus (Gmelin), the cellular responses were weaker to $S$. carpocapsae than in H. bacteriophora (Sheykhnejad et al. 2014). In another study, $6 \%$ encapsulation of $S$. feltiae was reported, while it was $24 \%$ in $H$. bacteriophora in Agriotes lineatus (L.) (Rahatkhah et al. 2015). Obtained results showed that the $S$. abbasi isolate $\mathrm{CS}_{2}$ had the strong capability to avoid encapsulation responses in larval $H$. armigera leading to the death of larvae within a very short time.

\section{Conclusion}

This study revealed that the presence of nematode within the hemolymph significantly decreased the amount of protein contents. The low encapsulation avoiding response led to a high number of nematode in hemolymph and subsequently reduced the amount of defensive proteins. More number of IJs in the hemolymph produced more toxins, which weaken the insect's immune system because of the quick death of the host larvae. The results showed that $S$. abbasi isolate $\mathrm{CS}_{2}$ had a high pathogenicity merit and provided an insight to use it as a better alternative of biological control agent in future insect pest management programs.

\section{Acknowledgements \\ Authors greatly acknowledge the Department of Zoology, Chaudhary Charan Singh University, Meerut, India, for providing infrastructure.}

\section{Authors' contributions}

Istkhar and AKC conceived and designed the study and critically revised the manuscript. Istkhar performed the experiments and analyzed the data. Both authors have approved the final manuscript.

\section{Funding}

Authors are thankful to Council of Scientific and Industrial Research (CSIR), New Delhi, India, for funding through EMR project (37(1550)/12-EMR-II).

\section{Availability of data and materials}

All data generated or analyzed during this study are included in this published article.

Ethics approval and consent to participate

Not applicable.

\section{Consent for publication}

Not applicable

\section{Competing interests}

The authors declare that they have no competing interests.

\section{Author details}

${ }^{1}$ Department of Bioscience and Biotechnology, Banasthali Vidyapith, Banasthali, Rajasthan 304022, India. ${ }^{2}$ Nematology Laboratory, Department of Zoology, Chaudhary Charan Singh University, Meerut, Uttar Pradesh 250004, India.

Received: 4 July 2019 Accepted: 23 September 2019

Published online: 15 November 2019

\section{References}

Bass C, Denholm I, Williamson MS, Nauen R (2015) The global status of insect resistance to neonicotinoid insecticides. Pestic Biochem Physiol 12:78-87 Bradford MM (1976) A rapid and sensitive method for the quantitation of microgram quantities of protein utilizing the principle of protein-dye binding. Anal Biochem 72:248-254

Brivio MF, Mastore M, Nappi AJ (2010) A pathogenic parasite interferes with phagocytosis of insect immunocompetent cells. Dev Comp Immunol 34: 991-998

Castillo JC, Reynolds SE, Eleftherianos I (2011) Insect immune responses to nematode parasites. Trends Parasitol 27(12):537-547. https://doi.org/10.1016/ j.pt.2011.09.001

Ebrahimi L, Niknam GH, Dunphy GB (2011) Hemocyte responses of Leptinotarsa decemlineata and Galleria mellonella to the entomopathogenic nematodes, Steinernemafeltiae and Heterorhabditis bacteriophora. J Insect Sci 11:76. https://doi.org/10.1673/031.011.7501

Ehlers RU, Wulff A, Peters A (1997) Pathogenicity of Axenic Steinernema feltiae, Xenorhabdus bovienii, and the bacto-helminthic complex to larvae of Tipula 
oleracea (Diptera) and Galleria mellonella (Lepidoptera). J Invertebr Pathol 69: 212-217

Feldhaar H, Gross R (2008) Immune reactions of insects on bacterial pathogens and mutualists. Microbes Infect. 10:1082-1088

Forst S, Nealson K (1996) Molecular biology of the symbiotic-pathogenic bacteria Xenorhabdus spp. and Photorhabdus spp. Microbiol Rev 60:21-43

Gillespie JP, Burnettand C, Charnley AK (2000) The immune response of the desert locust Schistocerca gregaria during mycosis of the fungus, Metarhizium anisopliae. J Physiol 46:429-437

Istkhar, Chaubey AK (2017) Impact of soil dwelling entomopathogenic nematodes, recovered from the soil of Uttar Pradesh (India), on cotton bollworm Helicoverpa armigera (Hübner) (Lepidoptera: Noctuidae). Appl Biol Res 19:63-70

Istkhar, Chaubey AK (2018) Challenging the larvae of Helicoverpa armigera and assessing the immune responses to nematode-bacterium complex. Phytoparasitica. 46(1):75-87. https://doi.org/10.1007/s12600-018-0640-3

Lacey LA, Georgis R (2012) Entomopathogenic nematodes for control of insect pests above and below ground with comments on commercial production. J Nematol 44:218-225

Laemmli UK (1970) Cleavage of structural proteins during the assembly of the head of bacteriophage T4. Nature 227:680-685

Lemaitre B, Hoffmann J (2007) The host defence of Drosophila melanogaster. Ann Rev Immunol 25:97-743

Li XY, Cowles EA, Cowles RS, Gaugler R, Cox-Foster DL (2009) Characterization of immunosuppressive surface coat proteins from Steinernemaglaseri that selectively kill blood cells in susceptible hosts. Mol Biochem Parasitol 165 162-169

Nagarkatti S, Prakash A (1974) Rearing of Heliothis armigera (Hubn) on artificial diet. Technical Bulletin of Commonwealth Institute of Commonwealth Institute of Biological Control, Bangalore, pp 17, pp 169-173

Patrícia Silva Golo PS, de Oliveira dos Santos AS, Monteiro CMO, de Souza Perinotto WM, Quinelato S, Camargo MG, de Sá FA, da Costa Al, Martins MF, de Azevedo Prata MC, Bittencourt VREP (2016) Lab-on-a-chip and SDS-PAGE analysis of hemolymph protein profile from Rhipicephalus microplus (Acari: Ixodidae) infected with entomopathogenic nematode and fungus. Parasito Res. https://doi.org/10.1007/s00436-016-5109-z

Peters A, Ehlers RU (1997) Encapsulation of the entomopathogenic nematode Steinernema feltiae in Tipula oleracea. J Invertebr Pathol 69(3):218-222

Rahatkhah Z, Karimi J, Ghadamyari M, Brivio MF (2015) Immune defenses of Agriotes lineatus larvae against entomopathogenic nematodes. BioControl 60: $641-653$

Schmidt O, Theopold U, Strand M (2001) Innate immunity and its evasion and suppression by hymenopteran endoparasitoids. Bioessays 23:344-351

Schmidt SP, Platzer EG (1980) Hemolymph composition of mosquito larvae infected with a mermithid nematode. J Nematol 10:299-304

Sheykhnejad H, Ghadamyari M, Ghasemi V, Jamali S, Karimi J (2014) Hemocytes immunity of rose sawfly, Arge ochropus (Hym.: Argidae) against entomopathogenic nematodes, Steinernema carpocapsae and Heterorhabditis bacteriophora. J Asia-Pac Entomol 17:879-883

Simões N, Caldas C, Rosa JS, Bonifassi E, Laumond C (2000) Pathogenicity caused by high virulent and low virulent strains of Steinermena carpocapsae to Galleria mellonella. J Invertebr Pathol 75:47-54

Singh OP (2005) Consumption pattern of insecticide in Helicoverpa armigera management in India. In: Saxena H, Rai AB, Ahmed R, Gupta S (eds) Recent Advances in Helicoverpa armigera Management. Indian Society of Pulses Research and Development, Kanpur, pp 17-24

Stock SP, Goodrich-Blair H (2012) Nematode parasites, pathogens and associates of insects and invertebrates of economic importance. In: Lacey LA (ed) Manual of Techniques in Invertebrate Pathology. Academic Press, London, pp 373-426

Toubarro D, Avila MM, Montiel R, Simões N (2013) A pathogenic nematode targets recognition proteins to avoid insect defenses. PLoS One. https://doi. org/10.1371/journal.pone.0075691

Wee KE, Yonan CR, Chang FN (2000) A new broadspectrum protease inhibitor from the entomopathogenic bacterium Photorhabdus luminescens. Microbiol 146:3141-3147

\section{Publisher's Note}

Springer Nature remains neutral with regard to jurisdictional claims in published maps and institutional affiliations.

\section{Submit your manuscript to a SpringerOpen ${ }^{\circ}$ journal and benefit from:}

- Convenient online submission

- Rigorous peer review

- Open access: articles freely available online

- High visibility within the field

- Retaining the copyright to your article

Submit your next manuscript at $\boldsymbol{\nabla}$ springeropen.com 